IRA-International Journal of Applied Sciences ISSN 2455-4499; Vol.05, Issue 02 (2016)

Institute of Research Advances

Pg. no. 66-73

http://research-advances.org/index.php/IRAJAS

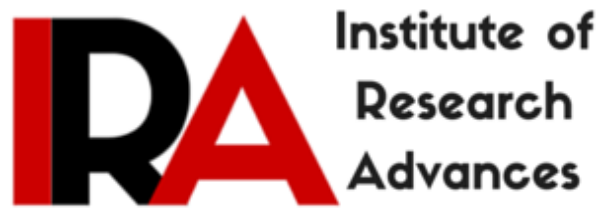

\title{
Vertical Flow Constructed Wetland for Treatment of Nitrogen Under Mesocosm Level Phragmites and Calamus Ecosystem of Gomutra
}

\author{
Dr. Parag Dalal \\ Assistant Professor, \\ Chemical Engineering Department, \\ Ujjain Engineering College, Ujjain, India.
}

Type of Review: Peer Reviewed.

DOI: http://dx.doi.org/10.21013/jas.v5.n2.p2

\section{How to cite this paper:}

Dalal, P. (2016). Vertical Flow Constructed Wetland for Treatment of Nitrogen Under Mesocosm Level Phragmites and Calamus Ecosystem of Gomutra. IRA-International Journal of Applied Sciences (ISSN 2455-4499), 5(2), 66-73. doi:http://dx.doi.org/10.21013/jas.v5.n2.p2

(C) Institute of Research Advances

\section{(cc) EY-NC}

This work is licensed under a Creative Commons Attribution-Non Commercial 4.0 International License subject to proper citation to the publication source of the work.

Disclaimer: The scholarly papers as reviewed and published by the Institute of Research Advances (IRA) are the views and opinions of their respective authors and are not the views or opinions of the IRA. The IRA disclaims of any harm or loss caused due to the published content to any party. 


\section{ABSTRACT}

This Vertical Flow Constructed Wetland (VFCW) system was evaluated for removal efficiency of Ammonium Nitrogen and Nitrate Nitrogen from Gomutra collected from cowsheds of Ujjain. The VFCW of mesocosm scale had a rectangular size and covered an effective area of $1.88 \mathrm{~m}^{2}$ with a water retention capacity of $0.206 \mathrm{~m}^{3}$. Two such units were combined together in series for better treatment performance. The VFCW was fabricated in a Reinforced Concrete Cement (RCC) tank below the ground level. The filter media was composed of coarse river sand supported below by coarse Gravel. Three sets were fabricated out of which-

- The first set was initially planted with locally available grass Phragmites;

- Second set was planted with Calamus at the rate of 10-12 plants per sq. m.

- Third set no plantation was there and considered as control.

In all the three sets, inlet and outlet arrangements were placed at top and bottom of the RCC tank respectively. The diluted Gomutra (1:4) was kept in dosing tank and allowed to pass through the VFCW; treated effluent was collected from each outlet. Phragmites bed $\mathrm{NH}_{4}-\mathrm{N}$ and $\mathrm{NO}_{3}-\mathrm{N}$ gets reduced by $71.6 \%$ and $51.96 \%$ respectively from inlet to outlet. Calamus bed causes a maximum reduction of $75.58 \%$ of $\mathrm{NH}_{4}-\mathrm{N}$ from inlet to outlet and for $\mathrm{NO}_{3}-\mathrm{N}$ it shows a reduction of $80.35 \%$ from inlet to outlet. The control reduces $\mathrm{NH}_{4}-\mathrm{N}$ by $13.94 \%$ and $\mathrm{NO}_{3}-\mathrm{N}$ by $14.28 \%$ from inlet to outlet.

The VFCW results established that

- This system is highly efficient for Gomutra treatment.

- Calamus bed system is most efficient in treatment of Gomutra in comparison to all three systems.

KEYWORDS: Calamus, Ammonium Nitrogen, Constructed wetland, Gomutra, Nitrate Nitrogen, Phragmites, Vertical Flow, Control, Reinforced Concrete Cement, water retention capacity

\section{INTRODUCTION}

The constructed wetlands is now most accepted low cost eco-technology, especially beneficial to isolated places that are not connected to the sewer lines for collection, disposals and treatment of wastewaters. The constructed wetlands can mimic natural systems as the water flows over the bed surface and is filtered through a dense stand of aquatic plants. The constructed wetlands can also promote vertical flow through a shallow permeable stratum in which aquatic plants are established. There are thousands of subsurface flow wetlands treating wastewaters.

The present study depicts treatment performance at mesocosm scale in VFCW for the treatment of Gomutra with Phragmites and Calamus bed systems, and to prove Ammonium-N and Nitrate-N removal efficiency of

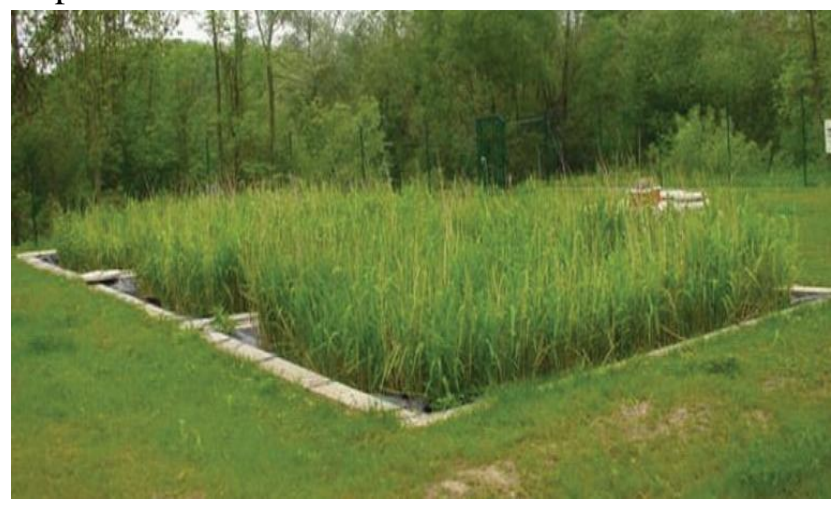
VFCW's and enhancing the medicinal properties of Gomutra. It is evident that Gomutra contains high amounts of nitrogenous species and other chemicals given below - 


\begin{tabular}{|c|c|}
\hline \multicolumn{2}{|c|}{ Quantitative Chemical Constitution of Cow Urine:- } \\
\hline Specific gravity & $1.025-1.045$ \\
\hline $\mathrm{pH}$ & 7.4- 8.4 \\
\hline Urea nitrogen & $23-28 \mathrm{ml} / \mathrm{kg} / \mathrm{day}$ \\
\hline Ammonium nitrogen & $1.0-1.7 \mathrm{ml} / \mathrm{kg} / \mathrm{day}$ \\
\hline Total nitrogen & 40- $45 \mathrm{ml} / \mathrm{kg} / \mathrm{day}$ \\
\hline Allantoin & $20-60 \mathrm{ml} / \mathrm{kg} /$ day \\
\hline Calcium & $0.1-1.4 \mathrm{~m} \mathrm{~mol} / \mathrm{kg} / \mathrm{day}$ \\
\hline Chloride & $0.1-1.1 \mathrm{~m} \mathrm{~mol} / \mathrm{kg} / \mathrm{day}$ \\
\hline Corproporphyrin & 5-14 microgram/dl \\
\hline Magnesium & $3-7 \mathrm{mg} / \mathrm{kg} /$ day \\
\hline Creatine & $15-20 \mathrm{mg} / \mathrm{kg} / \mathrm{day}$ \\
\hline Potassium & $0.08-0.15 \mathrm{~m} \mathrm{~mol} / \mathrm{kg} / \mathrm{day}$ \\
\hline Sodium & $0.2-1.1 \mathrm{~m} \mathrm{~mol} / \mathrm{kg} / \mathrm{day}$ \\
\hline Sulphate & $3-5 \mathrm{mg} / \mathrm{kg} /$ day \\
\hline Uric acid & $1-4 \mathrm{mg} / \mathrm{kg} /$ day. \\
\hline \multicolumn{2}{|l|}{ Enzymes:- } \\
\hline Lactate-Dehydrogenase & 21.780 unit \\
\hline Alkaline Phosphotase & 110.110 KA Unit \\
\hline Acid Phosphotase & 456.620 XA unit \\
\hline Amylase & 90.236 unit \\
\hline \multicolumn{2}{|l|}{ Other chemicals:- } \\
\hline Protein & $0.1037 \mathrm{gm} / \mathrm{lit}$ \\
\hline Uric Acid & $135.028 \mathrm{mg} / \mathrm{lit}$ \\
\hline Creatinine & $0.9970 \mathrm{~g} / \mathrm{lit}$ \\
\hline Lactate & $3.7830 \mathrm{~m}$ mole/lit \\
\hline Phenol & $4.7580 \mathrm{mg} / 100 \mathrm{~mL}$ \\
\hline Free volatile phenol & $0.7150 \mathrm{mg} / 100 \mathrm{~mL}$ \\
\hline Compound volatile phenol & $1.3420 \mathrm{mg} / 100 \mathrm{~mL}$ \\
\hline Aromatic hydroxy acid & $2.7030 \mathrm{mg} / 100 \mathrm{~mL}$ \\
\hline Calcium & $5.735 \mathrm{~m} \mathrm{~mol} / \mathrm{lit}$ \\
\hline Phosphorous & $0.4805 \mathrm{~m} \mathrm{~mol} / \mathrm{lit}$ \\
\hline
\end{tabular}

The Gomutra distillate has been patented Numbered US6410059, the patent, titled 'Pharmaceutical composition containing Gomutra distillate and an antibiotic'. The US Patent Office notes that 'the invention relates to an absolutely novel use of Gomutra distillate as activity enhancer and availability 
facilitator for bioactive molecules including anti-infective and anti-cancer agents. It has direct implication in drastically reducing the dosage of antibiotics, drugs and anti cancer agents while increasing the absorption of bioactive molecules."

The Calamus is wide spread among native people of India and North America. It is commonly found at old Indian villages and camping sites. Its rhizome and leaf has got a high medicinal use. Rhizome of Calamus are used extensively in traditional; medicine worldwide, its reported uses include stomach cramps, dysentery, asthma, brain tonic, stimulant, improve speaking ability, epilepsy and skin disease.

The Phragmites is a moisture loving grass found along riverbanks and in marshes. It transfers oxygen of the atmosphere to the bed of constructed wetland and provides purification to the liquid under treatment.

\section{METHODS AND MATERIAL}

Systems Design

A specific design was followed for sizing of each VFCW, based on the available RCC tanks and calculations the system was fabricated in May 2016. The RCC tank (Size: length $1.92 \mathrm{~m}$, width $0.80 \mathrm{~m}$, depth $0.75 \mathrm{~m}$, effective surface area $1.88 \mathrm{~m}^{2}$, and total volume $0.70 \mathrm{~m}^{3}$ ) was chosen for the construction of VFCW, as it was a waterproof and rigid structure. All together three-treatment units were constructed in series, each treatment unit consists of two VFCW combined together in series.

\section{Gomutra}

Fresh Gomutra was collected daily in suitable plastic containers of 20 liters capacity from different cowsheds of Ujjain. It was applied to wetland within $48 \mathrm{hrs}$ of its time of collection.

It is sold in market as Gomutra ark pricing Rs 30-80/ liter. Boiling of Gomutra at higher temperature may cause thermal disintegration of micronutrients, enzymes and chemical agents, which play major role as bio enhancer. Treatment of Gomutra under ambient temperature with constructed wetland is an attempt towards conserving its vital ingredients saving energy fuel and time.

The Bed

The bed of VFCW was a 0.4 m thick layer of washed and sieved coarse sand to provide bio-chemical, physical filtration of Gomutra. The sand was washed to remove attached dirt in order to get excess hydraulic conductivity. The filter media was laid over gravel bed of thickness $15 \mathrm{~cm}$. The porosity was maintained $30 \%$ and effective grain size $>0.05 \mathrm{~mm}$. The vertical bed system provides vigorous oxygenation to the bed, which leads to composition of aerobic environment in the bed.

The Inlet

To carry Gomutra distribution along the full surface area of mesocosm VFCW; the inlet was placed over the top of RCC tank along the length of the tank. The inlet duct and Gomutra distribution channel consist of $U$ shape PVC pipe of length $2 \mathrm{~m}$ with diameter $2.5 \mathrm{~cm}$ (fig). The distance between two distributors of $\mathrm{U}$ shape inlet was taken as $20 \mathrm{~cm}$. Each distributor arm consists of 5 orifices facing towards the bed the orifices were pierced in the distributor arm at an interval of $0.30 \mathrm{~m}$. The diluted Gomutra (1:4) was stored in dosing tanks and allowed to flow in inlet arrangement via a tube (fig).

\section{The Outlet}

The outlet system consists of a central manifold with laterals connected to it. Four pairs of laterals were connected to the central manifold for effective collection of treated Gomutra (fig). The discharge was collected a tap having elevation of $15 \mathrm{~cm}$ from the bottom of the RCC tank. This arrangement was made to achieve a retention period on daily basis.

Wetland vegetation

Two-plant species were selected as wetland vegetation and planted in sand bed of separate VFCW units to enhance the treatment efficiency of system constructed for treatment of Gomutra. 


\section{a. Phragmites}

b. Calamus

Phragmites and Calamus was planted over surface area of $1.88 \mathrm{~m}^{2}$ with plant density $15-18$ plants $/ \mathrm{m}^{2}$. No plantation was done in control.

Hydraulic loading rate

Hydraulic loading rate was set as $55-60$ liters/day. The loading rate was regulated with the help of a manual control valve.

Inlet arrangement

Outlet arrangement

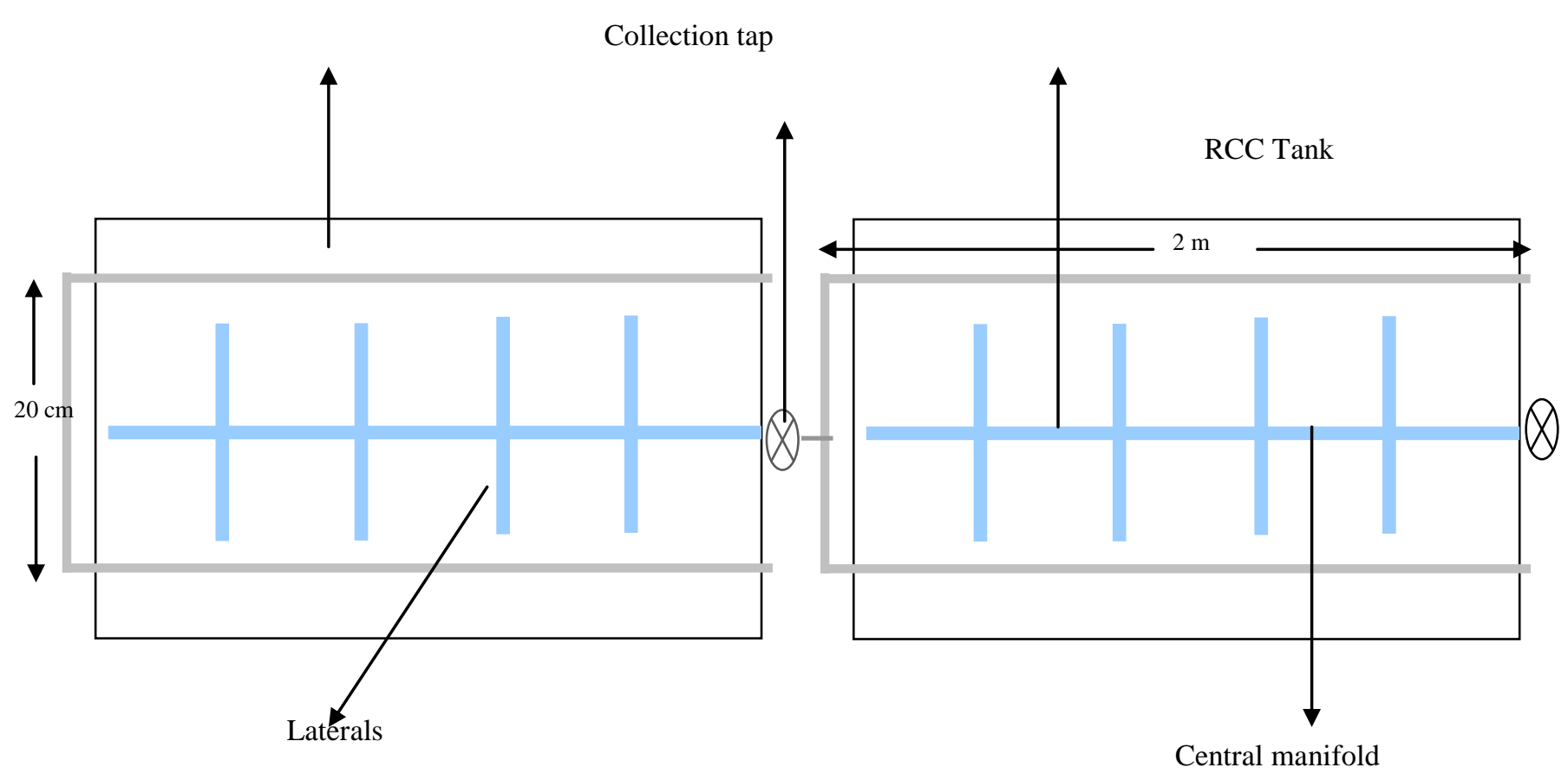

Fig 1. VFCW combined in series with cross-sectional inlet and outlet arrangement

\section{Capacity}

All the VFCW were designed for retention capacity of 150 liters and were designed for a retention period of 2 days.

\section{System Operation and Monitoring}

System require few months for vegetation and bio-film establishment and optimum time for stabilization. During this phase tap water was applied in the system, resulting into proliferation of rhizome and shoot of plants. After that diluted Gomutra (1:4) was regularly applied to the system and two parameters i.e. Ammonium nitrogen and nitrate nitrogen were monitored for evaluating the treatment performance. The parameters were analyzed using J.M. Bremner and D.R. Keeney basic steam distillation method 1965. 


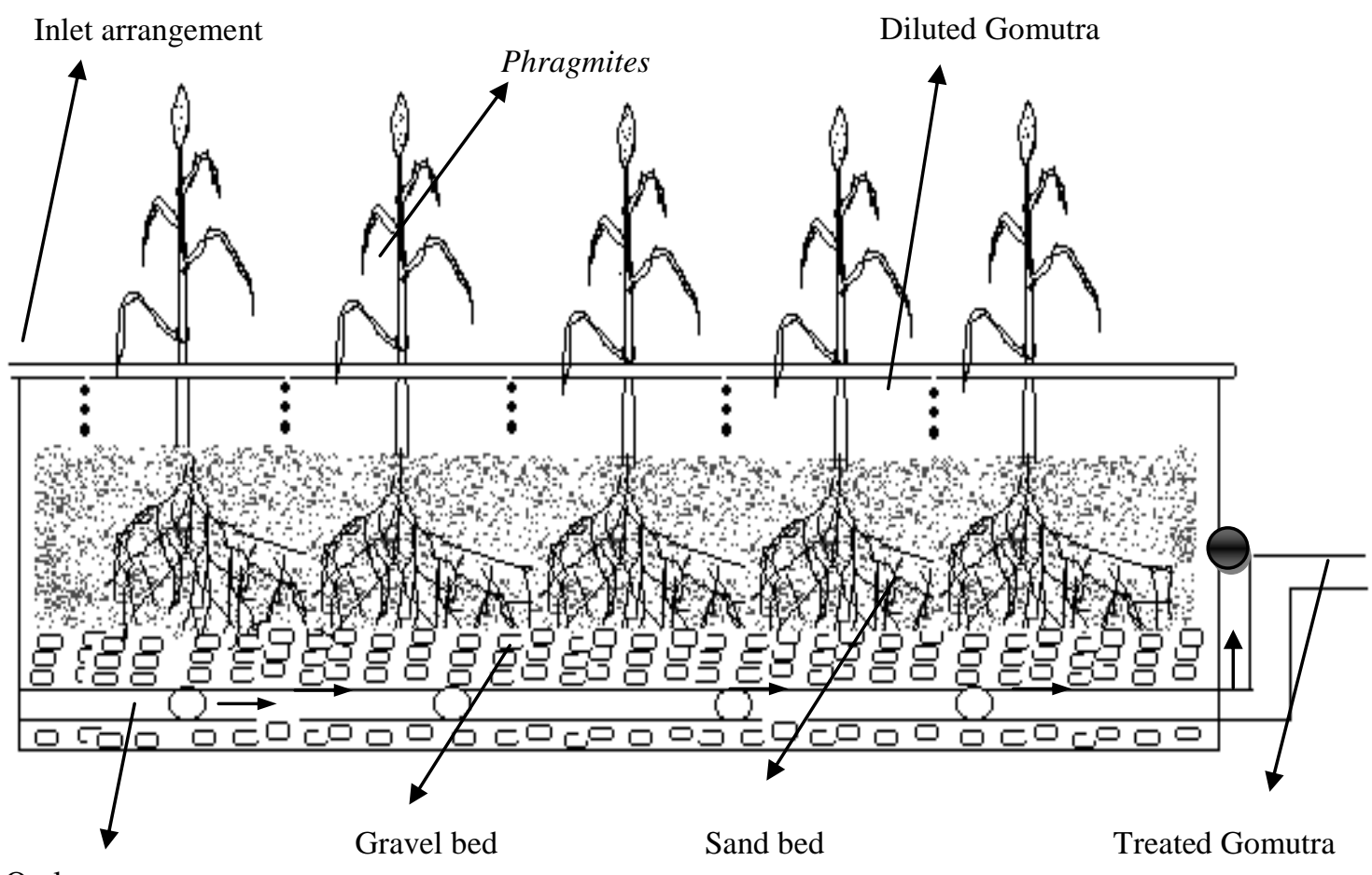

Fig 2. VFCW Cross-sectional view

\section{RESULT AND DISCUSSION}

The fabricated VFCW's provide a satisfactory treatment of Gomutra collected by large cowsheds for the treatment of Gomutra. After treatment it may be used and liquid manure, medicine, etc. for eradication of various diseases.

\section{Ammonium-N and Nitrate-N removal}

The VFCW's planted with Phragmites / Calamus and control showed different levels of removal percentages of nitrate- $\mathrm{N}$ and Ammonium-N from diluted Gomutra.

The basic treatment mechanism involves oxygenation, microbial interaction, plant uptake and adsorption. Table represents one month average treatment performance for influent and effluent concentrations. The system support high degree of oxygenation of liquid treatment as the air present in the voids of filter media comes in contact with the liquid. The rhizome of plants and bed provides a substratum for the growth of bio-film, which carry out biological oxidation of the organics and nitrogenous species present in the Gomutra.

Phragmites bed $\mathrm{NH}_{4}-\mathrm{N}$ and $\mathrm{NO}_{3}-\mathrm{N}$ gets reduced by $71.6 \%$ and $51.96 \%$ respectively from inlet to outlet. Calamus bed causes a maximum reduction of $75.58 \%$ of $\mathrm{NH}_{4}-\mathrm{N}$ from inlet to outlet and for $\mathrm{NO}_{3}-$ $\mathrm{N}$ it shows a reduction of $80.35 \%$ from inlet to outlet. The control reduces $\mathrm{NH}_{4}-\mathrm{N}$ by $13.94 \%$ and $\mathrm{NO}_{3}-$ $\mathrm{N}$ by $14.28 \%$ from inlet to outlet. 


\begin{tabular}{|l|l|l|l|}
\hline $\begin{array}{l}\text { Parameters } \\
(\mathrm{mg} / \mathrm{L})\end{array}$ & Inlet & Outlet & $\begin{array}{l}\text { Reduction } \\
\%\end{array}$ \\
\hline \multicolumn{4}{|c|}{ Phragmites bed } \\
\hline $\mathrm{NH}_{4}-\mathrm{N}$ & 74.3 & 21.1 & $71.60 \%$ \\
\hline $\mathrm{NO}_{3}-\mathrm{N}$ & 5.2 & 2.5 & $51.96 \%$ \\
\hline \multicolumn{4}{|c|}{ Calamus Bed } \\
\hline $\mathrm{NH}_{4}-\mathrm{N}$ & 73.3 & 17.9 & $75.58 \%$ \\
\hline $\mathrm{NO}_{3}-\mathrm{N}$ & 5.6 & 1.1 & $80.35 \%$ \\
\hline \multicolumn{4}{|c|}{ Control } \\
\hline $\mathrm{NH}_{4}-\mathrm{N}$ & 74.6 & 64.2 & $13.94 \%$ \\
\hline $\mathrm{NO}_{3}-\mathrm{N}$ & 5.6 & 4.8 & $14.28 \%$ \\
\hline
\end{tabular}

\section{CONCLUSION}

It is evident from this paper that plants play a major role in the treatment of Gomutra. The Calamus bed system is more efficient in reduction of $\mathrm{NH}_{4}-\mathrm{N}$ and $\mathrm{NO}_{3}-\mathrm{N}$ in comparison to Phragmites bed and control. The fabricated VFCW may provide a solution for the treatment of Gomutra for large and medium scale cowsheds and gaushalas before its final use. After providing treatment with Calamus bed it may be recommended for several uses. It is a cost effective and self sustained way for the treatment of Gomutra.

\section{REFERENCES}

1. Banrjee, G.C., (1998). Animal Husbandry. Oxford and IBH Pub. Co. Pvt. Ltd.

2. Bartnett, B., (1988). The miracle of urine therapy, water of the life institute, Florida.

3. Bremner, J.M. \& Keeney, D.R. (1965). Steam distillation methods for determination of ammonium, nitrate and nitrite $-\mathrm{N}$. Anal. Chem. Acta, 32:485-495.

4. Brix, H. (1996). Role of macrophytes in constructed wetlands. In: Preprints volume 1 of the $5^{\text {th }}$ International Conference on wetland Systems for water Pollution Control, Vienna, sept. 15-19, 1996. pp.2-1--2-6.

5. Chouhan, R.S. (2004). The Indian Cow, the scientific and economic journal, (Oct-Dec-2004) year 1 issue-2.

6. Cooper, P.F., Job, G.D., Green, M.B. and Shutes, R.B.E. (1996). Phragmites beds and constructed wetland for waste water treatment. WRc Swindon, UK. 184p

7. Devis, S.H., Ulmer, U.R., Strong, L., Catchart, T., Pote, J., and Brock, W., (1992), Constructed wetland for dairy wastewater treatment, American Society of Agriculture Engineers, Paper No. 924525, USA.

8. International Journal Of Cow Science, Panchgavya (Cowpathy): An Overview K Dhama, Rajesh Rathore, Rs Chauhan And Simmi Tomar

9. International Journal Of Immunopathology And Pharmacology Antimicrobial Property Of A Herbal Preparation containing Dalbergia Sissoo And Datura Stramonium With Cow Urine Against Pathogenic Bacteria H. Yadav, M. Yadav, S. Jain, A. Bhardwaj, V. Singh, O. Parkash And F. Marotta

10. International Journal Of Pharmaceutical Science Invention Clinical Evaluation Of Cow-Urine Extract Special Reference To Arsha (Hemorrhoids) Dr. Omaprakash W.Talokar, Dr.Archana R. Belge, Dr.Raman S. Belge

11. Kadlec, R.H. and Knight, R.L. (1996). Treatment Wetlands. CRC Press / Lewis Publishers, Boca Raton, Florida. 
12. Phragmites, S.C., Crites, R.W., and Middlebroods, E.J. (1995). Natural systems for waste management and treatment. $2^{\text {nd }}$ edition, McGraw-Hill, Inc., 433p

13. Singh, C., Jamwal Urmila, Singh, P., (2001). Calamus (Calamus); an overview of oil composition, biological activity and usage. Journal of medicinal and aromatic plant sciences

14. Vyamazal, J. (1996). Plants species used for constructed wetlands in the Czech republic. Paper presented at the $5^{\text {th }}$ Int. Conference on wetlands system for water pollution control Vienna, Australia.

15. Wood, A. (1995). Constructed wetlands in waster pollution control: Fundamentals to their understanding. Wat. Tech., 32 (3), 21-29. 